\title{
Regional Variation in the Index of Absorbance Difference as an Indicator of Maturity and Predictor of Storage Disorders in Apples
}

\author{
Renae Moran \\ School of Food and Agriculture, University of Maine, Monmouth, ME 04259 \\ Jennifer DeEll \\ Ontario Ministry of Agriculture, Food and Rural Affairs, Simcoe, Ontario, \\ Canada, N3Y 4N5
}

\section{Cindy B.S. Tong}

Department of Horticultural Science, University of Minnesota, Saint Paul, MN 55108

Additional index words. bitter pit, chilling injury, chlorophyll, fruit quality, internal ethylene concentration, Malus $\times$ sylvestris var. domestica, soft scald, soggy breakdown, starch pattern index

\begin{abstract}
We evaluated regional variation in the Delta Absorbance Meter ${ }^{\circledR}$ index of absorbance difference $\left(I_{\mathrm{AD}}\right)$ as a measure of harvest maturity and for predicting the occurrence of storage disorders in 'McIntosh' apples [Malus $\times$ sylvestris (L.) var. domestica (Borkh.) Mansf.] in 2016 and 'Honeycrisp' apples in 2016 and 2017. Apples were grown in Maine (ME), Minnesota (MN), and Ontario (ON), and they were harvested from one orchard in each region, and two to three times each year, followed by cold storage at $0.5{ }^{\circ} \mathrm{C}$ for 2 months in 2016 and 4 months in 2017. In 2016, 'Honeycrisp' $I_{A D}$ values were similar in ME and ON, but lower than in MN. In 2017, $I_{A D}$ was greater in $M E$ than in the other two regions during the first harvest, and it similar to $\mathrm{MN}$ in the latter two harvests and lower in $\mathrm{ON}$ than in the other regions. In 'Honeycrisp' apples, $I_{A D}$ was more strongly related to starch pattern index (SPI), internal ethylene concentration, and fruit peel blush than to chlorophyll or soluble solids concentration. Soft scald incidence (SSI) of 'Honeycrisp' fruit was greater in ME than in MN and ON in both years. In ME, SSI was related to $I_{A D}$ at harvest in both years, but with an inverse relationship with the first harvest and a positive relationship in the second harvest. A positive relationship also occurred in ON in 2017. SSI was not related to $I_{A D}$ at harvest in $M N$ in both years and $O N$ in 2016. Regional similarities in patterns of change in 'Honeycrisp' fruit $I_{A D}$ were not consistent from year to year, and this indicates that a single $I_{\mathrm{AD}}$ standard should not be used to assess fruit maturity in different regions. In 'McIntosh', $I_{A D}$ values were variable among the three regions and were not related to other maturity indicators. $I_{\mathrm{AD}}$ was not useful for measuring maturity in 'McIntosh' apples, but it was weakly related to core browning incidence.
\end{abstract}

'Honeycrisp' and 'McIntosh', two major cultivars in Canada and the United States, are prone to fruit quality loss and storage disorders that are directly influenced by harvest maturity (Smock, 1977; Watkins et al., 2005). Harvest at early stages of maturity can lead to bitter pit, whereas harvest at later stages can lead to chilling injury (CI) during storage in 'Honeycrisp' (Watkins et al., 2005). Harvest of 'McIntosh' at an early stage can lead to core browning and at advanced maturity to excessive softening (Meheriuk et al., 1994). To minimize these problems, growers depend on accurate measurement of fruit maturity at harvest.

Several maturity indicators are used to schedule harvest, but accuracy in measuring changes in maturity varies with the cultivar.
The starch pattern index (SPI) has been used as a fruit maturity indicator in many cultivars (Blanpied and Silsby, 1992), but it is not a consistent indicator of maturity in 'Honeycrisp' (Watkins et al., 2005). The starch pattern index is also influenced by crop load and weather in addition to fruit maturity (Serra et al., 2016; Smith et al., 1979). An increase in internal ethylene concentration (IEC) and ethylene production have been useful for determining when to complete harvest of 'McIntosh' (Blanpied and Silsby, 1992; Dilley and Dilley, 1985), but the rise in IEC does not consistently match advancing maturity in some varieties, or decreases from an initial spike in concentration (Doerflinger et al., 2016; Watkins et al., 2005). Ground color changes and chlorophyll breakdown occur in the peel during ripening (Knee,
1972), but this can be subjective in the case of ground color and difficult to measure on large numbers of fruit in the case of chlorophyll.

The Delta Absorbance Meter (DA meter) indirectly measures the decrease in chlorophyll $a$ concentration in the peel by measuring the index of absorbance difference $\left(\mathrm{I}_{\mathrm{AD}}\right)$ or the difference in absorbance at wavelengths 670 and $720 \mathrm{~nm}$. Because of its convenience, it has been tested on many cultivars including Honeycrisp, but harvest values may be region specific (DeLong et al., 2014) and cultivar dependent (Farneti et al., 2015; Nyasordzi et al., 2013). For 'Ambrosia' and 'Honeycrisp', $\mathrm{I}_{\mathrm{AD}}$ is a better measure of harvest maturity than SPI, which can be sensitive to yearly variation and crop load (Serra et al., 2016; Toivonen, 2015). An indicator of maturity should be consistent from year to year and from site to site within a region. Year-toyear and orchard-to-orchard stability occurred in the use of $\mathrm{I}_{\mathrm{AD}}$ as an indicator of when to harvest 'Ambrosia' (Toivonen, 2015). Consistency among orchards was reported for 'Honeycrisp' in the region of Nova Scotia (DeLong et al., 2014). Variation among regions may occur but has not been documented. Standards that are region- and cultivar-specific would be needed for accurate measurement of fruit maturity but can be cumbersome to deploy effectively for the many cultivars in production and for growers who manage several cultivars. Developing one standard for regions with similar growing conditions would simplify the use of $\mathrm{I}_{\mathrm{AD}}$ as an indicator of harvest maturity.

The ability to predict storage disorders at harvest could prevent loss of fruit if highly susceptible apples could be detected and segregated from apples placed in storage. This has been shown with superficial scald in the less susceptible 'Cripps Pink', but not in the highly susceptible 'Granny Smith' (Farneti et al., 2015). In 'Honeycrisp' grown in Nova Scotia, apples have reduced the risk of bitter pit and soft scald when $\mathrm{I}_{\mathrm{AD}}$ is in the range of 0.36 to 0.59 (DeLong et al., 2014). However, these studies were based on harvest means of $\mathrm{I}_{\mathrm{AD}}$, and they do not consider the variation of maturity that can occur within one harvest date or additional factors involved in disorder development (such as air temperature and precipitation) that also change with time while fruit remain on the tree to further ripen. Segregation of fruit into $\mathrm{I}_{\mathrm{AD}}$ classes may increase our understanding of how maturity influences susceptibility to soft scald and bitter pit without the interference of other orchard factors that change with calendar date, a necessary step in developing predictive models.

The objective of this research was to evaluate the regional variation and predictive capabilities of harvest $\mathrm{I}_{\mathrm{AD}}$ in 'Honeycrisp' and 'McIntosh' apples to determine the universality of $\mathrm{I}_{\mathrm{AD}}$ as a harvest indicator. 


\section{Materials and Methods}

'McIntosh' and 'Honeycrisp' fruit were grown, harvested, and stored in three regions with similar growing conditions: Monmouth, ME (lat. 44 $13^{\prime} 51^{\prime \prime} \mathrm{N}$, long. $70^{\circ} 4^{\prime} 5^{\prime \prime} \mathrm{W}$ ),

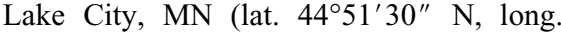
$93^{\circ} 39^{\prime} 41^{\prime \prime}$ W), and Norfolk County, ON (lat. $42^{\circ} 52^{\prime} 44^{\prime \prime} \mathrm{N}$, long. $80^{\circ} 15^{\prime} 22.6^{\prime \prime} \mathrm{W}$ ). The same orchard in each location was used in both 2016 and 2017. Although only one orchard was sampled in each region, each represents different soil and weather conditions of the Midwest and Northeastern United States. In ME, trees were grafted to 'M.26' and 'Geneva 16 ' rootstocks and were planted in 2002. 'Honeycrisp'/'M.26' trees in ON were planted in 1998. In $\mathrm{MN}$, trees grafted to 'B.9' were planted circa 1997. In 2016, fruit from 'Roger's Red McIntosh'/'M.7 EMLA' in ME, 'Summerland McIntosh'/'M.7' in $\mathrm{ON}$, and 'Ruby Mac' in MN were included in the study.

Date of harvest was based on preliminary maturity estimates of a few fruit using SPI. In 2016, at each location, fruit were harvested randomly, without regard to color, size, or canopy position, three times at weekly intervals beginning 8,13 , and 14 Sept. in $\mathrm{MN}$, $\mathrm{ME}$, and ON, respectively, for 'McIntosh'; and 31 Aug., 14 and 15 Sept. for MN, ON, and ME, respectively, for 'Honeycrisp', except in $\mathrm{ON}$ where fruit were harvested twice. Replications each consisted of at least three trees to minimize individual tree effects and 45 to 70 fruit per replication in ME; 40 to 75 'Honeycrisp' and 40 to 120 'McIntosh' fruit per replication in $\mathrm{MN}$; and 85 'Honeycrisp' and 100 'McIntosh' fruit per replication in ON. In 2017, three replications each with 60 fruit were randomly harvested three times at weekly intervals beginning 18 Sept. in MN. In ME, 55 to 80 apples were harvested from each of two replications at weekly intervals beginning $15 \mathrm{Sept}$. In ON, one replication of

Received for publication 20 May 2020. Accepted for publication 7 July 2020.

Published online 6 August 2020.

This research was conducted as multistate project NE1336. We are grateful for funding from the Ontario Apple Growers, Canadian Horticultural Council, and the Minnesota Agricultural Experiment Station for project \#MN 21-028; the Maine Agricultural \& Forest Experiment Station, project \#ME0-31404; and by the U.S. Department of Agriculture National Institute of Food and Agriculture.

We thank Pepin Heights Orchard for their collaboration, and Hsueh-Yuan Chang, Ben Ma, and Samantha Putlak for help with assays in Minnesota. Mention of a trademark, proprietary product, or vendor does not constitute a guarantee or warranty of the product, nor does it imply approval or disapproval to the exclusion of other products or vendors that may also be suitable.

R.M. is the corresponding author. E-mail: rmoran@ maine.edu.

This is an open access article distributed under the CC BY-NC-ND license (https://creativecommons.org/ licenses/by-nc-nd/4.0/).
250 fruit from several trees were harvested at weekly intervals beginning 7 Sept. 'McIntosh' apples were not studied in 2017.

Apples were numbered with a fine-tip permanent ink marker on the peel at the interface of sun and shade exposure and near the stem end to identify fruit and later match $\mathrm{I}_{\mathrm{AD}}$ at harvest with post-storage disorders and fruit quality, but also to indicate where to sample peel for chlorophyll analysis. The same day or one day after harvest, $\mathrm{I}_{\mathrm{AD}}$ was measured on two sides of each apple on an area below the ink mark and on the opposite side of the fruit, avoiding any areas with sunburn. If $\mathrm{I}_{\mathrm{AD}}$ readings on opposite sides of an apple substantially varied from one another, an additional reading was made to confirm or reject the disparity. Values that indicated potential sunbleaching were rejected. All measurements were made with a Delta Absorbance Meter (Sinteleia, Bologna, Italy). Fruit were grouped in increments of $0.2 \mathrm{I}_{\mathrm{AD}}$ units for fruit quality measurements. Fruit weight of each apple and the amount of fruit surface area (2017 only) with blush were measured on each apple. Five to ten fruit from each $\mathrm{I}_{\mathrm{AD}}$ group were used to measure SPI, soluble solids content (SSC), and firmness on two peeled sides of each fruit. Some $I_{A D}$ groups had insufficient fruit for both maturity and storage, so harvest measurements were not made for these groups. Starch staining with iodine was measured by dipping or spraying each cross-sectioned apple in or with a potassiumiodine solution and using a visual rating where $1=$ all starch remaining and $8=$ no starch (Blanpied and Silsby, 1992). Flesh firmness was measured using a drill press-mounted penetrometer (McCormick Fruit Tester model FT 327, Alfonsine, Italy) in MN; an electronic texture analyzer (Guss Manufacturing, Strand, South Africa) in ON; and an EPT-1 (Lake City Technical Products, Kelowna, BC, Canada) in $\mathrm{ME}$; all equipped with an 11-mm diameter plunger. Soluble solids concentration was measured using a hand-held temperaturecompensated refractometer [Atago model PAL-1 3810A in ME and MN; and an Atago PR-32 in ON (Tokyo, Japan)] from a pooled sample in ME and $\mathrm{ON}$ and from individual fruit in MN. Juice was expressed during pressure testing.

Internal ethylene concentration (IEC) was measured at harvest and after storage on fruit harvested in ON. A 3-mL gas sample was withdrawn from the core of each of five fruit within an $\mathrm{I}_{\mathrm{AD}}$ group using a syringe and then injected into an Agilent 7820A gas chromatograph (Agilent Technologies Canada Inc., Mississauga, Ontario, Canada) equipped with a $0.25-\mathrm{mL}$ sample loop, flame ionization detector, and a $25-\mathrm{m} \times 0.53-\mathrm{mm}$ CarboBOND capillary column (Agilent Technologies Canada Inc.). The injector, column, and detector temperatures were 150,80 , and $250{ }^{\circ} \mathrm{C}$, respectively. High-grade helium was used as the carrier gas, with a typical run time of $1.5 \mathrm{~min}$.

Chlorophyll measurements were made only on fruit harvested from MN and ON. Fruit from ON were shipped via overnight freight to $\mathrm{MN}$ where all chlorophyll measurements were made using a modification of the method described by DeLong et al. (2014). Peel discs (1.4 cm in diameter) were removed from each of 15-20 fruit of each harvest of $\mathrm{MN}$ and $\mathrm{ON}$, transferred to $1.5-\mathrm{mL}$ tubes (one sample per fruit per tube), frozen in liquid $\mathrm{N}_{2}$, and stored at $-80{ }^{\circ} \mathrm{C}$ until extracted. Samples were removed from approximate, not exact, areas where $\mathrm{I}_{\mathrm{AD}}$ measurements were made. Samples were pulverized with tungsten beads using a TissueLyser II (Qiagen, Germantown, MD) at $30 \mathrm{~Hz}$ for $5 \mathrm{~min}$. After disruption, $1 \mathrm{~mL} 95 \%$ (190 proof) ethanol was added to each tube. Tubes were mixed by inversion, and then centrifuged at 10,000 $g_{n}$ for $5 \mathrm{~min}$. Supernatants $(100 \mu \mathrm{L}$ each sample $)$ were transferred to a 96-well plate, and absorbances were measured at $665 \mathrm{~nm}$ and $645 \mathrm{~nm}$ using a SpectraMax 190 spectrophotometer (Molecular Devices, San Jose, CA) equipped with SoftMaxPro 5.2 software. Blank wells contained 95\% (190 proof) ethanol. Total chlorophyll content was calculated using the equation described by Lichtenthaler (1987) for 95\% (v/v) ethanol as a solvent with a slight modification in absorbance wavelengths but using peel area equal to $\pi(0.7 \mathrm{~cm})^{2}$. The equation was as follows:

$$
\text { chl a }=13.36(\mathrm{~A} 665)-5.19(\mathrm{~A} 649) .
$$

In all three locations, fruit were stored at $0.5{ }^{\circ} \mathrm{C}$ in air for 2 months in 2016 and 4 months in 2017. The longer duration was tested in 2017 to allow for full development of storage disorders. Following storage, incidences of soft scald, soggy breakdown, bitter pit, lenticel blotch, lenticel breakdown, senescent breakdown, diffuse flesh browning, and core browning were counted.

Statistical analyses. The main effects of harvest date and location and their interaction were subjected to analysis of variance using the MIXED procedure and means separation by Tukey's honestly significant difference, using SAS software version 9.1 (SAS Institute, Inc, Cary, NC). Relationship of fruit maturity, quality, and incidence of disorders with $\mathrm{I}_{\mathrm{AD}}$ at harvest was determined by regression analysis using the REG and RSREG procedures.

\section{Results}

$I_{A D}$ at harvest. In both years, 'Honeycrisp' fruit peel $\mathrm{I}_{\mathrm{AD}}$ varied among harvest dates and location with a significant interaction between the two factors (Table 1). In 2016, $\mathrm{I}_{\mathrm{AD}}$ was greater in $\mathrm{MN}$ than in ME and $\mathrm{ON}$ during each harvest. It also decreased with later harvest date in $\mathrm{MN}$ and ME, but not in ON where the two harvest dates were only $5 \mathrm{~d}$ apart. In 2017, $\mathrm{I}_{\mathrm{AD}}$ decreased with later harvest date in all three locations, but the decrease in $\mathrm{MN}$ was not significant from harvest 2 to harvest 3 , which is similar to what occurred in 2016 in this location. In 2017, $\mathrm{I}_{\mathrm{AD}}$ was consistently higher in ME than 
Table 1. Fruit peel $\mathrm{I}_{\mathrm{AD}}$ at three harvest times in 'McIntosh' and 'Honeycrisp' apples grown in three regions.

\begin{tabular}{|c|c|c|c|c|c|}
\hline \multirow[b]{2}{*}{ Region } & \multicolumn{2}{|c|}{ Harvest date } & \multicolumn{2}{|c|}{ Honeycrisp } & \multirow{2}{*}{$\frac{\text { McIntosh }}{2016}$} \\
\hline & 2016 & 2017 & 2016 & 2017 & \\
\hline \multirow[t]{3}{*}{$\mathrm{MN}$} & 31 Aug. $^{z}$ & 18 Sept. & $1.17 \mathrm{a}^{\mathrm{y}}$ & $0.79 \mathrm{~b}$ & $1.64 \mathrm{~d}$ \\
\hline & 8 Sept. & 26 Sept. & $0.94 \mathrm{~b}$ & $0.48 \mathrm{~cd}$ & $1.56 \mathrm{~d}$ \\
\hline & 14 Sept. & 3 Oct. & $0.94 \mathrm{~b}$ & $0.35 \mathrm{de}$ & $1.49 \mathrm{e}$ \\
\hline \multirow[t]{3}{*}{$\mathrm{ON}$} & 14 Sept. & 7 Sept. & $0.65 \mathrm{~d}$ & $0.60 \mathrm{c}$ & $1.26 \mathrm{f}$ \\
\hline & 19 Sept. & 14 Sept. & $0.58 \mathrm{de}$ & $0.31 \mathrm{e}$ & $1.18 \mathrm{~g}$ \\
\hline & - & 21 Sept. & - & $0.18 \mathrm{f}$ & - \\
\hline \multirow[t]{3}{*}{ ME } & 15 Sept. & 15 Sept. & $0.81 \mathrm{c}$ & $1.21 \mathrm{a}$ & $1.92 \mathrm{a}$ \\
\hline & 22 Sept. & 28 Sept. & $0.63 \mathrm{~d}$ & $0.57 \mathrm{c}$ & $1.80 \mathrm{~b}$ \\
\hline & 28 Sept. & 10 Oct. & $0.28 \mathrm{e}$ & $0.43 \mathrm{~d}$ & $1.69 \mathrm{c}$ \\
\hline \multicolumn{6}{|c|}{$P$ values for ANOVA Type III sums of squares } \\
\hline Region (R) & & & 0.0001 & 0.0001 & 0.0001 \\
\hline Harvest $(\mathrm{H})$ & & & 0.0001 & 0.0001 & 0.0001 \\
\hline $\mathrm{R} \times \mathrm{H}$ & & & 0.0001 & 0.0283 & 0.0001 \\
\hline
\end{tabular}

${ }^{\mathrm{z}}$ 'McIntosh' dates were 7 to $8 \mathrm{~d}$ later in MN and were $2 \mathrm{~d}$ prior in ME.

${ }^{\mathrm{y}}$ Means separation by Tukey's test. Letters within a column followed by the same letter are not significantly different, $5 \%$ level.

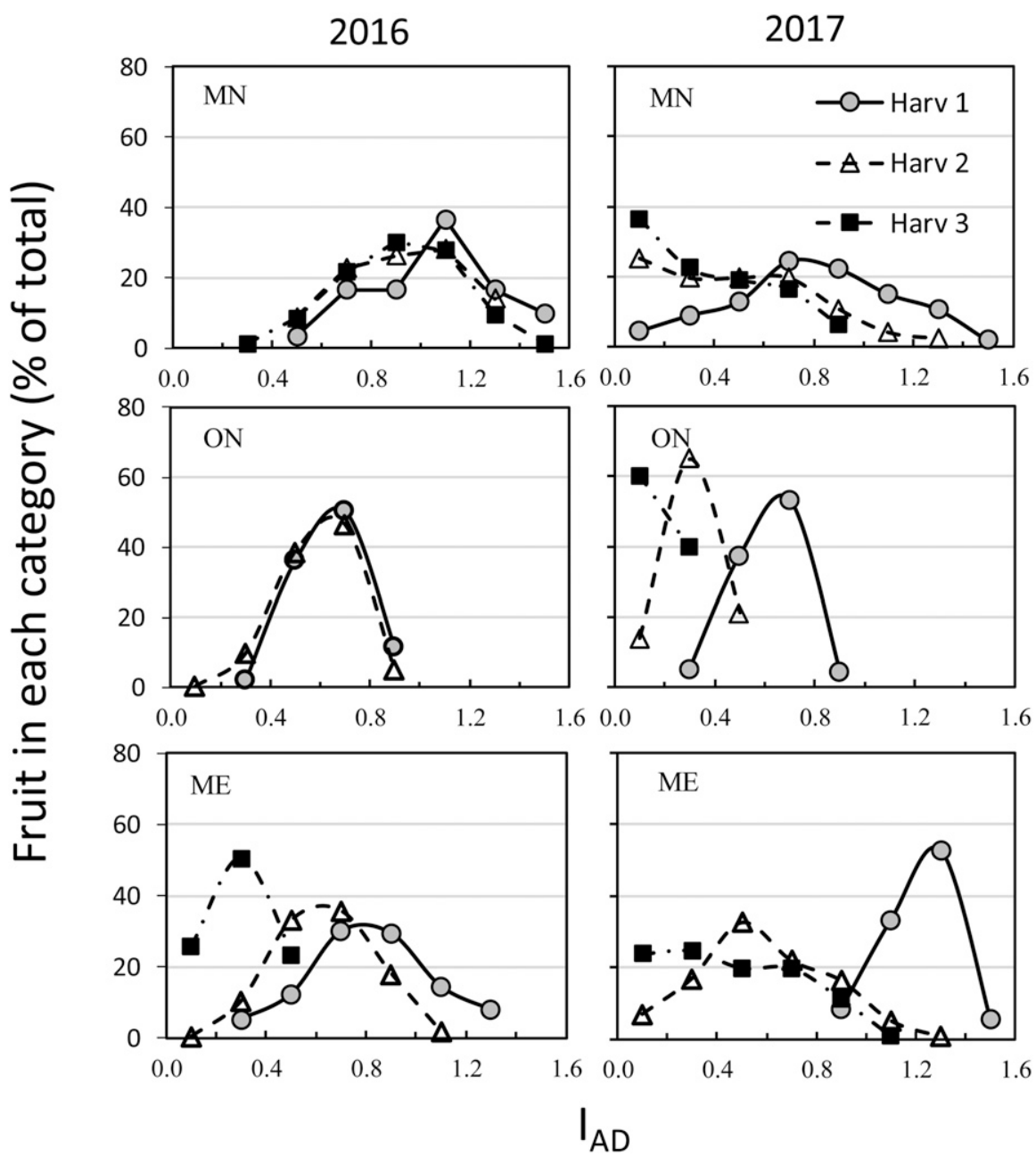

Fig. 1. Distribution of $\mathrm{I}_{\mathrm{AD}}$ values as a percentage of the total harvested 'Honeycrisp' apples at three harvest dates in 2016-17. In 2016, the total number of fruit at each harvest in ME was 195, 190, and 214 at harvests 1,2, and 3, respectively; in MN it was 120, 225, and 225 at harvests 1, 2, and 3 respectively; in ON it was 170 at each harvest. In 2017, the total number of fruit at each harvest in ME was 108, 160, and 126 at harvests 1,2, and 3, respectively; in MN it was 120 at each harvest; in ON it was 250 at each harvest.

in $\mathrm{ON}$ and higher than in $\mathrm{MN}$ during the first harvest.

A wide range in $\mathrm{I}_{\mathrm{AD}}$ occurred within a harvest date in 'Honeycrisp' in both years (Fig. 1). In $\mathrm{MN}, \mathrm{I}_{\mathrm{AD}}$ ranged from 0.5 to 1.5 during the first harvest of 2016 and from 0.1 to 1.5 in 2017 . Wide ranges occurred in subsequent harvests, as well. There was substantial overlap in $\mathrm{I}_{\mathrm{AD}}$ values among the three harvests and a lack of a distinct peak in $\mathrm{I}_{\mathrm{AD}}$

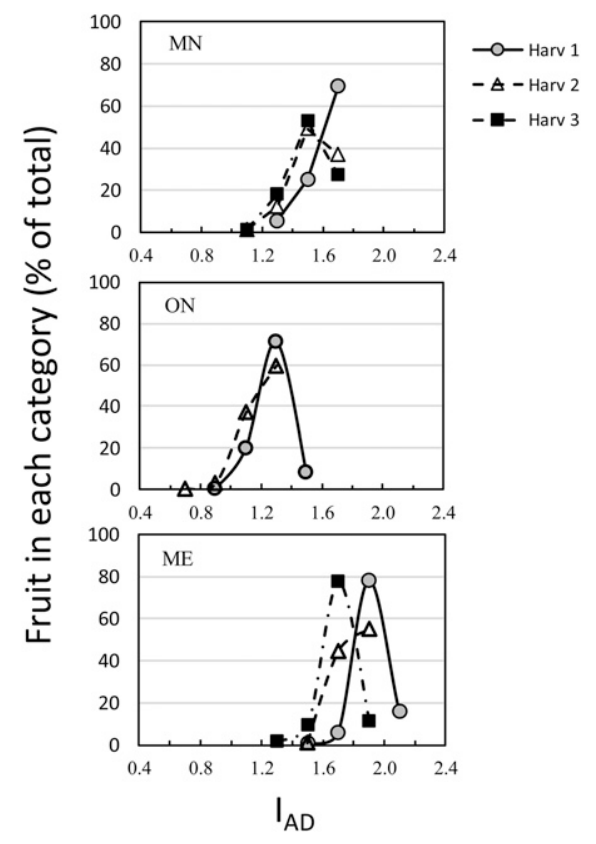

Fig. 2. Distribution of $I_{A D}$ values as a percentage of all harvested 'McIntosh' apples at three harvest dates in 2016. The total number of fruit at each harvest in ME was 195, 135, and 135 at harvests 1,2, and 3, respectively; in MN it was 120,270 , and 360 at harvests 1,2 , and 3 respectively; in ON it was 200 at each harvest.

values in $\mathrm{MN}$ and ME. Substantial overlap also occurred in ON in 2016, but a clear peak in $\mathrm{I}_{\mathrm{AD}}$ occurred during both harvest dates with $50 \%$ and $46 \%$ of the fruit having $\mathrm{I}_{\mathrm{AD}}$ near 0.7 during the first and second harvests, respectively. A similar peak in $\mathrm{I}_{\mathrm{AD}}$ occurred in 2017, but with a clear shift to lower values in later harvests.

Peel $\mathrm{I}_{\mathrm{AD}}$ was higher in 'McIntosh' than in 'Honeycrisp' in all regions. In 'McIntosh', region and harvest date affected $\mathrm{I}_{\mathrm{AD}}$ with an interaction between the two factors. Peel $\mathrm{I}_{\mathrm{AD}}$ decreased with later harvest in each region, but in $\mathrm{MN}$ no change occurred between harvests 1 and 2. Regional differences occurred with $\mathrm{ME}$ having the highest $\mathrm{I}_{\mathrm{AD}}, \mathrm{MN}$ having intermediate values, and $\mathrm{ON}$ having the lowest.

In 'McIntosh', $\mathrm{I}_{\mathrm{AD}}$ values within a harvest date were distributed over a narrow range compared with 'Honeycrisp' (Fig. 2). Substantial overlap occurred in MN during harvests 2 and 3, and in $\mathrm{ON}$ during both harvests. In ME, there was less overlap among harvest dates, and a clear peak in $\mathrm{I}_{\mathrm{AD}}$ near 1.9, 1.9, and 1.7 during harvests 1,2 , and 3 , respectively.

Fruit maturity. Chlorophyll $a$ in 'Honeycrisp' was related to $\mathrm{I}_{\mathrm{AD}}$ in fruit from the first harvest, but not the later harvests, and the range in concentrations was similar in both regions (Fig. 3). Chlorophyll was not measured in ME, nor in 2017 in any location. The range of concentration in 'McIntosh' was generally similar to that of 'Honeycrisp'. Chlorophyll $a$ concentration in 'McIntosh' was related to $\mathrm{I}_{\mathrm{AD}}$ in $\mathrm{MN}$-grown fruit from the second harvest, but otherwise, it was not 


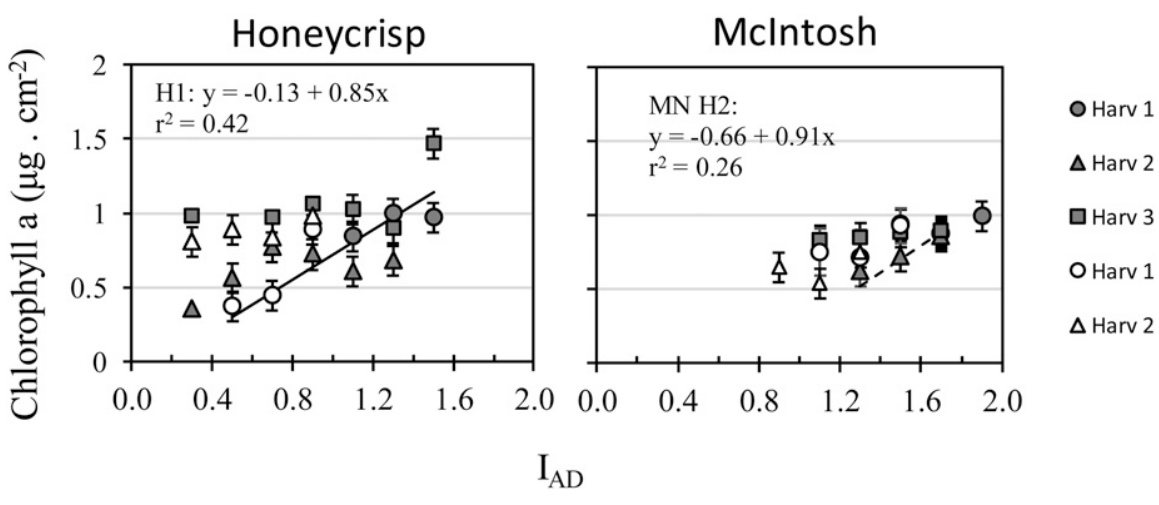

Fig. 3. The relationship between chlorophyll $a$ concentration in 'Honeycrisp' and 'McIntosh' fruit peel and the $\mathrm{I}_{\mathrm{AD}}$ at harvest. Fruit grown in $\mathrm{MN}$ (open symbols) were harvested on three dates, and it was harvested twice in ON (shaded symbols) in 2016. The regression equation for 'Honeycrisp' is for both regions and all harvest dates. The regression equation for 'McIntosh' is for fruit from the MN second harvest. Each point is a mean of three replications.

related to $\mathrm{I}_{\mathrm{AD}}$. The low $r^{2}$ indicates that $\mathrm{I}_{\mathrm{AD}}$ explained less than half the variation in measured chlorophyll $a$ concentration.

Internal ethylene concentration in fruit from $\mathrm{ON}$ (not measured in $\mathrm{MN}$ or $\mathrm{ME}$ ) varied with $\mathrm{I}_{\mathrm{AD}}$, but not with harvest date in 'Honeycrisp'. In both years, IEC was negatively related to $\mathrm{I}_{\mathrm{AD}}$ (Fig. 4), so higher IEC occurred with lower $\mathrm{I}_{\mathrm{AD}}$. In 2016, the relationship was the same for the two harvest dates; but in 2017, IEC varied with $\mathrm{I}_{\mathrm{AD}}$ during harvests 1 and 2 , but not during harvest 3 when the range in $\mathrm{I}_{\mathrm{AD}}$ values was narrow. In 'McIntosh', IEC was not related to $\mathrm{I}_{\mathrm{AD}}$ because most fruit had undetectable levels (not shown).

The starch pattern index did not vary with harvest date when $\mathrm{I}_{\mathrm{AD}}$ was included in the statistical analysis, indicating a colinear relationship between the two variables (Table 2). In 'Honeycrisp', SPI was linearly and negatively related to $\mathrm{I}_{\mathrm{AD}}$ in each region with no interactions, indicating similar relationship to $\mathrm{I}_{\mathrm{AD}}$ in the different regions. In $\mathrm{MN}$, the relationship to $\mathrm{I}_{\mathrm{AD}}$ was not significant during harvest 1 , most likely because of the narrow range in $\mathrm{I}_{\mathrm{AD}}$ (Fig. 5) and in $\mathrm{ON}$ during harvest 2 when starch breakdown was

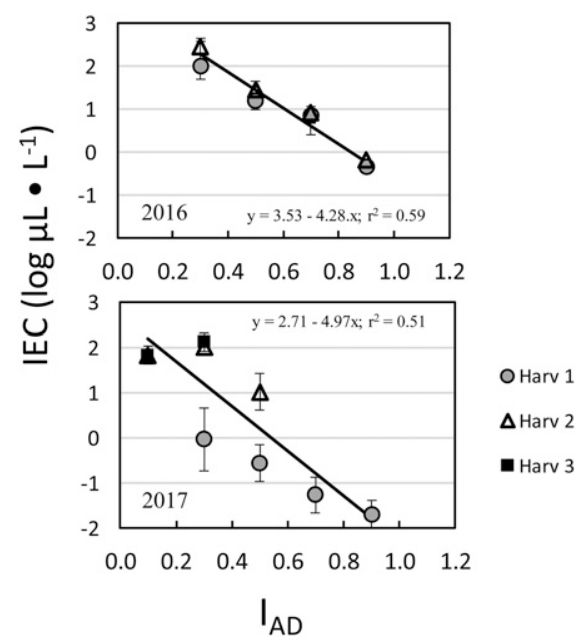

Fig. 4. Internal ethylene concentration (IEC) at harvest of ON-grown 'Honeycrisp'. IEC is shown as the log of its concentration. nearly complete. In ME, SPI was related to $\mathrm{I}_{\mathrm{AD}}$ in harvests 1 and 2. In 2017, SPI in 'Honeycrisp' was negatively related to $\mathrm{I}_{\mathrm{AD}}$ in all regions with no interactions with region or harvest. Within each region, the same relationship between SPI and $\mathrm{I}_{\mathrm{AD}}$ occurred for the three harvest dates, but the $r^{2}$ was low in $\mathrm{MN}$. In ME, the relationship was curvilinear because of complete starch breakdown at $\mathrm{I}_{\mathrm{AD}}$ values lower than 0.7. In 'McIntosh', SPI did not vary among regions and varied little with harvest date and $\mathrm{I}_{\mathrm{AD}}$ (Table 2).

Fruit quality. Fresh weight, as a measure of fruit size, of 'Honeycrisp' in 2016 generally increased with later harvest and was linearly related to $\mathrm{I}_{\mathrm{AD}}$, but with an interaction with region and harvest (Table 3). In MN, fruit weight decreased at higher $\mathrm{I}_{\mathrm{AD}}$ values with the second harvest only (not shown). In $\mathrm{ME}$ and $\mathrm{ON}$, fruit weight increased at higher $\mathrm{I}_{\mathrm{AD}}$ values, but this relationship was only significant for harvest 2 in $\mathrm{ON}$ and harvests 1 and 3 in ME. These mixed results indicate that no consistent trend occurred between fruit fresh weight and $\mathrm{I}_{\mathrm{AD}}$. In 2017, fruit weight varied among regions but not other factors. Fruit from MN were smaller than fruit from $\mathrm{ON}$ and ME. In 'McIntosh', fruit significantly different, $5 \%$ level. weight was larger in $\mathrm{MN}$ than in the other two regions and did not vary with harvest or $\mathrm{I}_{\mathrm{AD}}$.

The amount of peel area that had red coloration, measured in 'Honeycrisp' fruit in 2017, varied with harvest date and $\mathrm{I}_{\mathrm{AD}}$, but not among regions (Table 3). Peel color generally increased with later harvest and was negatively related to $\mathrm{I}_{\mathrm{AD}}$ in all three locations (Fig. 6). Within a region, the linear relationship was similar for all three harvests, although the coefficients of determination varied from 0.4 to 0.8 among regions.

Firmness varied among regions for fruit of 'Honeycrisp' (Table 4). In general, firmness was lower in fruit from MN than $\mathrm{ON}$ and $\mathrm{ME}$, and it decreased with later harvest. Firmness of 'Honeycrisp' fruit at harvest in 2016 was linearly related to $\mathrm{I}_{\mathrm{AD}}$, but not in a consistent or meaningful way (not shown) - sometimes positively, sometimes negatively, and in many instances, with no evident linear relationship. Firmness after storage decreased with later harvest date and was not related to $\mathrm{I}_{\mathrm{AD}}$. 'Honeycrisp' fruit firmness in 2017 was not related to harvest date or to $\mathrm{I}_{\mathrm{AD}}$. 'McIntosh' fruit firmness in 2016 was not related to harvest date, but firmness after storage varied with $\mathrm{I}_{\mathrm{AD}}$. In fruit from $\mathrm{ON}$, firmness was lower with higher $\mathrm{I}_{\mathrm{AD}}(y=12.5$ $\left.-2.3 x ; r^{2}=0.39\right)$, but significant relationships did not occur in $\mathrm{MN}$ or ME.

Soluble solids concentration in 'Honeycrisp' fruit at harvest was greater in ME than in $\mathrm{ON}$ and $\mathrm{MN}$ in 2016 (Table 5). Greater SSC occurred with harvest 2 than with harvest 3 . After storage, SSC did not vary with harvest date or region. There was a linear, negative relationship between $\mathrm{SSC}$ and $\mathrm{I}_{\mathrm{AD}}$ at harvest in $\mathrm{MN}$ and after storage in $\mathrm{ON}$ (Fig. 7). In ME, SSC was not related to $\mathrm{I}_{\mathrm{AD}}$ (not shown). In 2017, SSC was not related to $\mathrm{I}_{\mathrm{AD}}$. In 'McIntosh', SSC did not vary among harvests, regions, or $\mathrm{I}_{\mathrm{AD}}$ values (Table 5).

Storage disorders. Incidence of bitter pit in 'Honeycrisp' fruit was not related to $\mathrm{I}_{\mathrm{AD}}$ at harvest in either year and did not vary with harvest date in $\mathrm{MN}$ or ME. Bitter pit incidence in 2016 in ME was $11 \%, 8 \%$, and

Table 2. Starch pattern index at three harvest dates in 'Honeycrisp' and 'McIntosh' apples grown in three regions. Starch index was judged on a scale of 1 to 8 , with 8 indicating complete breakdown.

\begin{tabular}{lccc}
\hline & \multicolumn{2}{c}{ Honeycrisp } & McIntosh \\
\cline { 2 - 3 } Factor & 2016 & 2017 & 2016 \\
\hline $\mathrm{MN}$ & 5.0 & $7.5 \mathrm{a}^{\mathrm{z}}$ & 4.1 \\
$\mathrm{ON}$ & 6.2 & $5.8 \mathrm{~b}$ & 4.7 \\
$\mathrm{ME}$ & 5.9 & $7.6 \mathrm{a}$ & 5.7 \\
Harvest 1 & 4.4 & 6.6 & 4.5 \\
Harvest 2 & 6.4 & 7.5 & 4.6 \\
Harvest 3 & 6.0 & 7.8 & 5.3 \\
& P values for ANOVA Type III sums of squares & \\
Region (R) & 0.6003 & 0.0132 & 0.3589 \\
Harvest (H) & 0.6693 & 0.1699 & 0.8276 \\
$\mathrm{I}_{\mathrm{AD}}$ Linear (L) & 0.0001 & 0.0025 & 0.3704 \\
$\mathrm{R} \times \mathrm{H}$ & 0.8682 & 0.3512 & 0.8844 \\
$\mathrm{R} \times \mathrm{I}_{\mathrm{AD}} \mathrm{L}$ & 0.0952 & 0.2295 & 0.7699 \\
$\mathrm{H} \times \mathrm{I}_{\mathrm{AD}} \mathrm{L}$ & 0.2366 & 0.5640 & 0.8133 \\
$\mathrm{R} \times \mathrm{H} \times \mathrm{I}_{\mathrm{AD}} \mathrm{L}$ & 0.5927 & 0.1978 & 0.8972 \\
\hline
\end{tabular}

${ }^{\mathrm{z}}$ Means separation by Tukey's test. Letters within a column followed by the same letter are not 


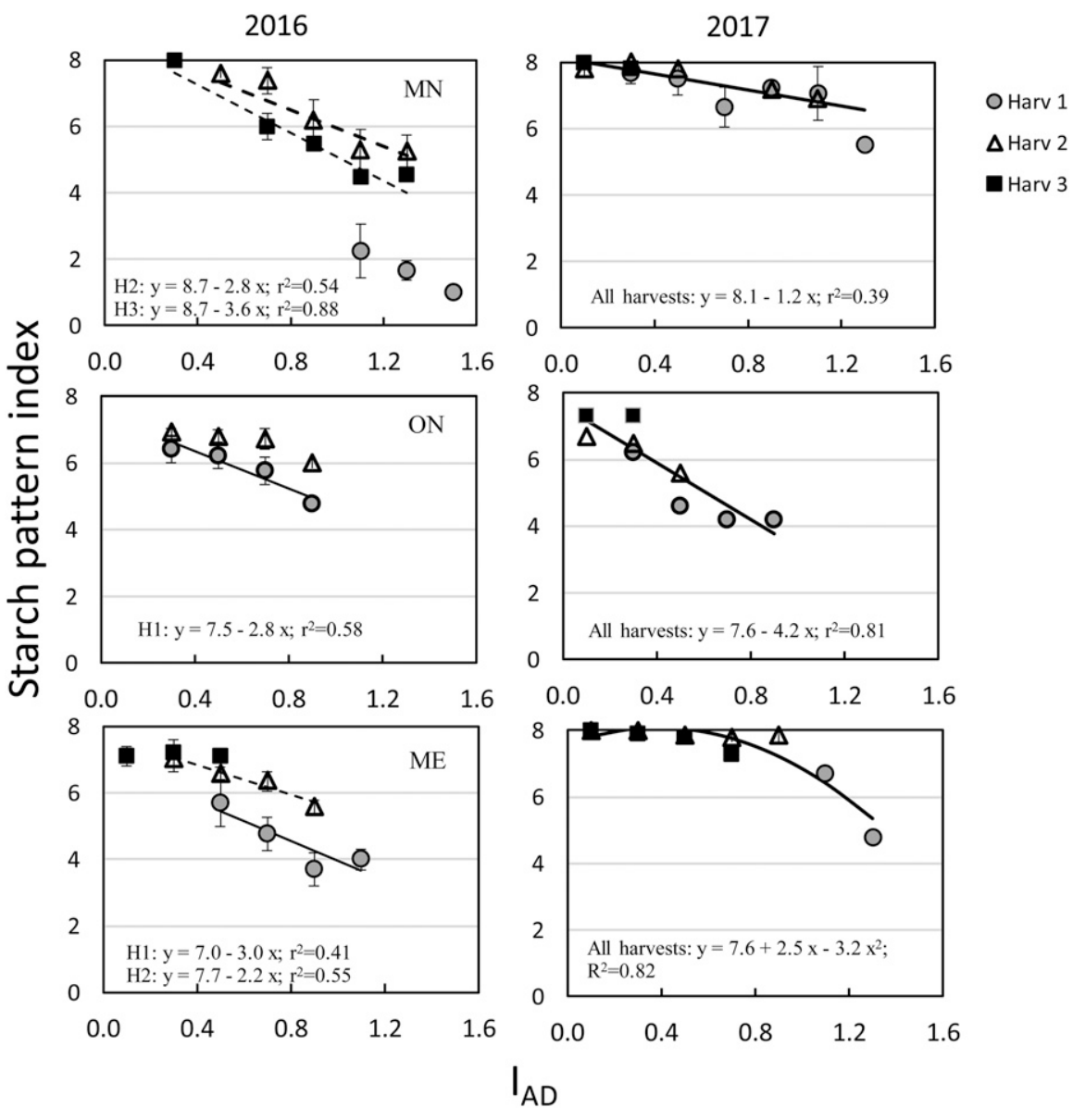

Fig. 5. The relationship between starch pattern index at three harvest dates of 'Honeycrisp' fruit and fruit peel $\mathrm{I}_{\mathrm{AD}}$ at harvest. $\mathrm{H} 1, \mathrm{H} 2$, and $\mathrm{H} 3$ indicate harvests 1, 2, and 3, respectively.

Table 3. Mean fresh weight (g) at three harvest dates of 'Honeycrisp' and 'McIntosh' apples, and red color as a percentage of the peel surface of 'Honeycrisp' apples grown in three regions.

\begin{tabular}{|c|c|c|c|c|}
\hline \multirow[b]{3}{*}{ Factor } & \multicolumn{3}{|c|}{ Fruit fresh wt (g) } & \multirow{3}{*}{$\begin{array}{c}\frac{\text { Fruit color }(\% \text { blush })}{\text { Honeycrisp }} \\
2017\end{array}$} \\
\hline & \multicolumn{2}{|c|}{ Honeycrisp } & \multirow{2}{*}{$\frac{\text { McIntosh }}{2016}$} & \\
\hline & 2016 & 2017 & & \\
\hline$\overline{\mathrm{MN}}$ & 179 & $157 \mathrm{~b}$ & $170 \mathrm{a}$ & 70 \\
\hline ON & 174 & $236 \mathrm{a}$ & $125 \mathrm{~b}$ & 62 \\
\hline ME & 244 & $217 \mathrm{a}$ & $136 \mathrm{~b}$ & 52 \\
\hline Harvest 1 & $192 c^{z}$ & 177 & 139 & 58 \\
\hline Harvest 2 & $200 \mathrm{~b}$ & 192 & 143 & 60 \\
\hline Harvest 3 & $221 \mathrm{a}$ & 211 & 170 & 68 \\
\hline \multicolumn{5}{|c|}{$P$ values for ANOVA Type III sums of squares } \\
\hline Region (R) & 0.2360 & 0.0172 & 0.0535 & 0.9173 \\
\hline Harvest $(\mathrm{H})$ & 0.0004 & 0.1814 & 0.3023 & 0.0481 \\
\hline $\mathrm{I}_{\mathrm{AD}} \operatorname{Linear}(\mathrm{L})$ & 0.0016 & 0.5042 & 0.3034 & 0.0001 \\
\hline $\mathrm{R} \times \mathrm{H}$ & 0.4878 & 0.2791 & 0.4076 & 0.4914 \\
\hline $\mathrm{R} \times \mathrm{I}_{\mathrm{AD}} \mathrm{L}$ & 0.0001 & 0.3671 & 0.1081 & 0.4115 \\
\hline $\mathrm{H} \times \mathrm{I}_{\mathrm{AD}} \mathrm{L}$ & 0.0379 & 0.2153 & 0.4737 & 0.0768 \\
\hline $\mathrm{R} \times \mathrm{H} \times \mathrm{I}_{\mathrm{AD}} \mathrm{L}$ & 0.0847 & 0.8910 & 0.8420 & 0.9579 \\
\hline
\end{tabular}

${ }^{\mathrm{z}}$ Means separation by Tukey's test. Letters within a column followed by the same letter are not significantly different, $5 \%$ level.

$5 \%$; and it was $0 \%, 2 \%$, and $0 \%$ in $\mathrm{MN}$ for the first, second, and third harvests, respectively. In ON, bitter pit did not occur in 2016, but it was severe in 2017 when incidence was $7 \%$, $13 \%$, and $31 \%$ for each harvest, respectively. In 2017 , bitter pit was less severe in ME than in the previous year, and it was $2 \%, 0 \%$, and $0.4 \%$ for each respective harvest. In $\mathrm{MN}$, bitter pit occurrence in 2017 was similar to that observed in 2016: $0 \%, 0 \%$, and $2 \%$ for each respective harvest. The occurrence of diffuse flesh browning varied with year and harvest date, but it was not related to $\mathrm{I}_{\mathrm{AD}}$ (data not shown). Diffuse flesh browning was more prevalent in 2017 than in 2016 in both $\mathrm{ON}$ and $\mathrm{ME}$, where it was greater in fruit from the third harvest than in the first or second.

Soft scald occurred in 'Honeycrisp' fruit in all three regions in both years (Table 6). Fruit were not conditioned before cold stor-

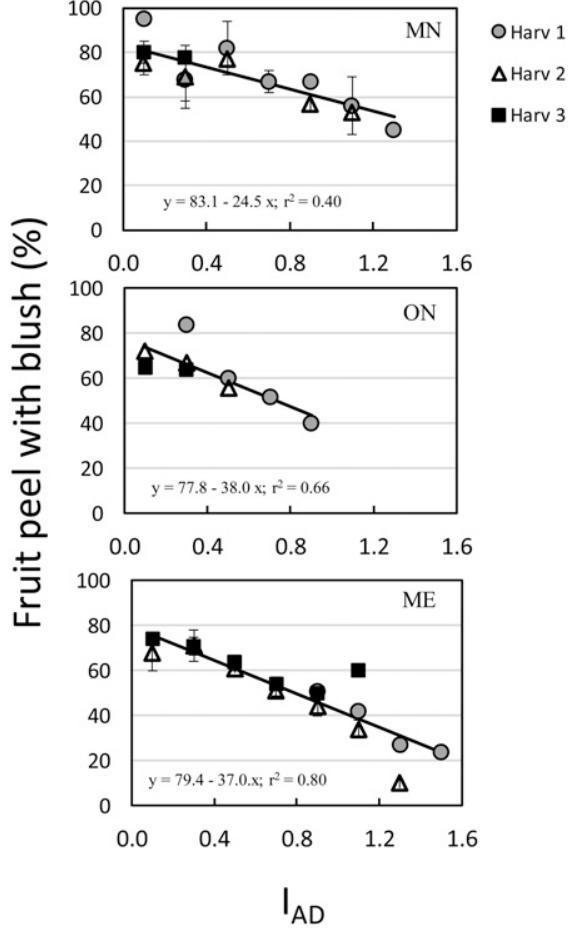

Fig. 6. The relationship between red peel color of 'Honeycrisp' fruit and $\mathrm{I}_{\mathrm{AD}}$ at harvest in fruit from three regions and three harvest dates in 2017.

age to induce full expression of the disorder. Incidence in 2016 was lower in $\mathrm{MN}$ and $\mathrm{ON}$ than in ME, where it was severe. There was no relationship with $\mathrm{I}_{\mathrm{AD}}$ in 2016 in $\mathrm{MN}$ and ON (Fig. 8). In ME, SSI was related to $\mathrm{I}_{\mathrm{AD}}$, but the relationship varied considerably between the three harvests. Soft scald was negatively related to $\mathrm{I}_{\mathrm{AD}}$ in fruit from harvest 1 ; positively related to $\mathrm{I}_{\mathrm{AD}}$ in fruit from harvest 2; and not related to $\mathrm{I}_{\mathrm{AD}}$ with harvest 3 , when it was severe for all $\mathrm{I}_{\mathrm{AD}}$ categories. In 2017, SSI was not related to $\mathrm{I}_{\mathrm{AD}}$ in $\mathrm{MN}$. Fruit from harvest 1 had greater SSI than later harvests in $\mathrm{MN}$, as well as in ON. In ON, SSI was positively related to $\mathrm{I}_{\mathrm{AD}}$ with all three harvests. In ME, the relationship to $\mathrm{I}_{\mathrm{AD}}$ occurred in a similar manner as in 2016, when SSI was negatively related to $\mathrm{I}_{\mathrm{AD}}$ for the first harvest and positively related with $\mathrm{I}_{\mathrm{AD}}$ values for harvests 2 and 3.

Soggy breakdown incidence in 'Honeycrisp' varied with region, harvest, and $\mathrm{I}_{\mathrm{AD}}$ with an interaction among all three factors in both years (Table 6). In ON, soggy breakdown did not occur. In MN, soggy breakdown was greater with harvest 3 than the other harvests in 2016; did not vary with harvest date in 2017; and did not vary with $\mathrm{I}_{\mathrm{AD}}$ (Fig. 9). In ME, soggy breakdown was related to $\mathrm{I}_{\mathrm{AD}}$ in a similar manner as with SSI in 2016. In 2017, soggy breakdown was related to $\mathrm{I}_{\mathrm{AD}}$ with harvest 3 and not with the previous harvests.

Disorders did not occur in 'McIntosh' grown in ME or ON. 'McIntosh' fruit grown in $\mathrm{MN}$ developed core browning and soft scald. There was a weak, positive relationship between core browning incidence and 
Table 4. Flesh firmness $(\mathrm{N})$ at harvest and after storage at $0.5^{\circ} \mathrm{C}$ of 'Honeycrisp' and 'McIntosh' apples grown in three regions.

\begin{tabular}{|c|c|c|c|c|c|c|}
\hline \multirow[b]{3}{*}{ Factor } & \multicolumn{4}{|c|}{ Honeycrisp } & \multirow{2}{*}{\multicolumn{2}{|c|}{$\begin{array}{c}\text { McIntosh } \\
2016\end{array}$}} \\
\hline & \multicolumn{2}{|c|}{2016} & \multicolumn{2}{|c|}{2017} & & \\
\hline & Harvest & Stored & Harvest & Stored & Harvest & Stored \\
\hline$\overline{\mathrm{MN}}$ & $52.9 \mathrm{~b}^{\mathrm{z}}$ & $52.8 \mathrm{~b}$ & 54.6 & $50.7 \mathrm{~b}$ & $55.5 \mathrm{c}$ & $36.2 \mathrm{~b}$ \\
\hline $\mathrm{ON}$ & $74.3 \mathrm{a}$ & $72.8 \mathrm{a}$ & 70.4 & $70.6 \mathrm{a}$ & $70.0 \mathrm{~b}$ & $44.0 \mathrm{~b}$ \\
\hline $\mathrm{ME}$ & $75.4 \mathrm{a}$ & $75.3 \mathrm{a}$ & 61.4 & $61.4 \mathrm{ab}$ & $80.2 \mathrm{a}$ & $54.7 \mathrm{a}$ \\
\hline Harvest 1 & $72.7 \mathrm{~A}$ & $70.2 \mathrm{~A}$ & 58.5 & 58.9 & 70.1 & 45.6 \\
\hline Harvest 2 & $65.8 \mathrm{~B}$ & $62.7 \mathrm{AB}$ & 59.0 & 56.7 & 66.8 & 43.1 \\
\hline Harvest 3 & $58.9 \mathrm{C}$ & $52 \mathrm{~B}$ & 69.8 & 58.4 & 62.4 & 41.7 \\
\hline \multicolumn{7}{|c|}{ P values for ANOVA Type III sums of squares } \\
\hline Region (R) & 0.0003 & 0.0001 & 0.0001 & 0.0001 & 0.0142 & 0.0049 \\
\hline Harvest $(\mathrm{H})$ & 0.0214 & 0.0029 & 0.6132 & 0.1415 & 0.8303 & 0.9544 \\
\hline $\mathrm{I}_{\mathrm{AD}}$ Linear $(\mathrm{L})$ & 0.0083 & 0.2676 & 0.8195 & 0.2921 & 0.1962 & 0.0123 \\
\hline $\mathrm{R} \times \mathrm{H}$ & 0.0019 & 0.1601 & 0.0222 & 0.3206 & 0.7379 & 0.5804 \\
\hline $\mathrm{R} \times \mathrm{I}_{\mathrm{AD}} \mathrm{L}$ & 0.4443 & 0.2884 & 0.8498 & 0.9035 & 0.1328 & 0.1301 \\
\hline $\mathrm{H} \times \mathrm{I}_{\mathrm{AD}} \mathrm{L}$ & 0.8144 & 0.1230 & 0.9440 & 0.5347 & 0.9267 & 0.8804 \\
\hline $\mathrm{R} \times \mathrm{H} \times \mathrm{I}_{\mathrm{AD}} \mathrm{L}$ & 0.0486 & 0.5520 & 0.6346 & 0.9993 & 0.8124 & 0.6087 \\
\hline
\end{tabular}

${ }^{\mathrm{z}}$ Means separation by Tukey's test. Letters within a column followed by the same letter are not significantly different, $5 \%$ level. Lowercase letters indicate differences among regions, and uppercase letters among harvests.

Table 5. Soluble solids concentration (\%) at harvest and after $0.5{ }^{\circ} \mathrm{C}$ storage of 'Honeycrisp' and 'McIntosh' apples grown in three regions.

\begin{tabular}{|c|c|c|c|c|c|c|}
\hline \multirow[b]{3}{*}{ Factor } & \multicolumn{4}{|c|}{ 'Honeycrisp' } & \multirow{2}{*}{\multicolumn{2}{|c|}{$\begin{array}{c}\text { 'McIntosh' } \\
2016 \\
\end{array}$}} \\
\hline & \multicolumn{2}{|c|}{2016} & \multicolumn{2}{|c|}{2017} & & \\
\hline & At harvest & $\overline{\text { Stored }}$ & At harvest & $\overline{\text { Stored }}$ & At harvest & $\overline{\text { Stored }}$ \\
\hline$\overline{\mathrm{MN}}$ & $11.5 \mathrm{c}^{\mathrm{z}}$ & 11.7 & 12.8 & 12.9 & 12.1 & 12.3 \\
\hline $\mathrm{ON}$ & $13.2 \mathrm{~b}$ & 13.4 & 12.0 & 11.6 & 12.6 & 13.8 \\
\hline $\mathrm{ME}$ & $13.8 \mathrm{a}$ & 13.9 & 11.9 & 11.6 & 14.0 & 14.1 \\
\hline Harvest 1 & $12.8 \mathrm{AB}$ & 13.3 & 12.0 & 11.6 & 12.6 & 12.8 \\
\hline Harvest 2 & $12.9 \mathrm{~A}$ & 12.6 & 12.1 & 12.2 & 12.7 & 13.6 \\
\hline \multirow[t]{2}{*}{ Harvest 3} & $12.4 \mathrm{~B}$ & 11.3 & 12.4 & 12.1 & 13.2 & 13.2 \\
\hline & \multicolumn{4}{|c|}{$P$ values for ANOVA Type III sums of squares } & & \\
\hline Region (R) & 0.0039 & 0.2625 & 0.1601 & 0.3030 & 0.1521 & 0.9634 \\
\hline Harvest $(\mathrm{H})$ & 0.0346 & 0.0995 & 0.6101 & 0.7793 & 0.6779 & 0.8573 \\
\hline $\mathrm{I}_{\mathrm{AD}}$ Linear $(\mathrm{L})$ & 0.0072 & 0.0353 & 0.3588 & 0.7115 & 0.4651 & 0.6163 \\
\hline $\mathrm{R} \times \mathrm{H}$ & 0.3052 & 0.1205 & 0.6852 & 0.7287 & 0.9274 & 0.7736 \\
\hline $\mathrm{R} \times \mathrm{I}_{\mathrm{AD}} \mathrm{L}$ & 0.2429 & 0.5356 & 0.5446 & 0.8891 & 0.6904 & 0.8894 \\
\hline $\mathrm{H} \times \mathrm{I}_{\mathrm{AD}} \mathrm{L}$ & 0.5005 & 0.3922 & 0.2491 & 0.8825 & 0.4377 & 0.9637 \\
\hline $\mathrm{R} \times \mathrm{H} \times \mathrm{I}_{\mathrm{AD}} \mathrm{L}$ & 0.3291 & 0.3013 & 0.7907 & 0.9912 & 0.4358 & 0.5515 \\
\hline
\end{tabular}

${ }^{\mathrm{z}}$ Means separation by Tukey's test. Letters within a column followed by the same letter are not significantly different, 5\% level. Lowercase letters indicate differences among regions, and uppercase letters among harvests.

$\mathrm{I}_{\mathrm{AD}}$ with harvests 2 and $3\left(r^{2}=0.26\right)$. At $\mathrm{I}_{\mathrm{AD}}$ values below 1.5 , no core browning occurred; but above this, core browning increased to $20 \%$ at an $\mathrm{I}_{\mathrm{AD}}$ of 1.7 (not shown). No core browning occurred with harvest 1 . Soft scald occurred in 5\% of the 'McIntosh' apples grown in $\mathrm{MN}$, but incidence was not related to $\mathrm{I}_{\mathrm{AD}}$ (not shown).

\section{Discussion}

The $\mathrm{I}_{\mathrm{AD}}$ should change in a measurable way and in parallel with later harvest date or advancing maturity. This has been shown to occur in 'Ambrosia' (Toivonen, 2015), 'Aurora Golden Gala' (Toivonen and Hampson, 2014), 'Empire' (Doerflinger et al., 2016), 'Honeycrisp' (DeLong et al., 2014) and 'Starking' (Nyasordzi et al., 2013) fruit. In this study, we found a reduction in $\mathrm{I}_{\mathrm{AD}}$ values with later harvest dates in 'Honeycrisp' and 'McIntosh' fruit, but sometimes differences were slight, particularly in 'McIntosh' fruit. $\mathrm{I}_{\mathrm{AD}}$ values of 'Honeycrisp' fruit were similar to previous reports (DeLong et al., 2014; Serra et al., 2016), but none are available for 'McIntosh' fruit.

In this study, fruit were randomly harvested to estimate the range in $\mathrm{I}_{\mathrm{AD}}$ within a harvest date. A notable difference between the two cultivars was the wider range in $\mathrm{I}_{\mathrm{AD}}$ values in 'Honeycrisp' fruit, both within harvest date and during the harvest period, suggesting that ripening is more uneven in 'Honeycrisp' than in 'McIntosh'. An additional difference was the higher $\mathrm{I}_{\mathrm{AD}}$ values in 'McIntosh' compared with 'Honeycrisp' fruit, despite somewhat similar chlorophyll $a$ concentration. This occurs in 'Granny Smith' and 'Starking', as well, where both had similar chlorophyll concentration but widely varying $\mathrm{I}_{\mathrm{AD}}$ (Nyasordzi et al., 2013). The high $\mathrm{I}_{\mathrm{AD}}$ values and distribution of $\mathrm{I}_{\mathrm{AD}}$ values around a distinct peak in 'McIntosh' fruit was similar to the distribution for 'Granny Smith' fruit, whereas the wider range in values without the distinct peak in 'Honeycrisp' fruit was similar to that in 'Cripps Pink' fruit (Farneti et al., 2015) and previously reported values for 'Honeycrisp' (Serra et al., 2016).

The stage of maturity that determines when to harvest should be indicated by the same $\mathrm{I}_{\mathrm{AD}}$ from year to year, and it should be consistent with postharvest performance. In 'Ambrosia' fruit, $\mathrm{I}_{\mathrm{AD}}$ is more consistent from year to year than SPI in determining when to harvest for firmness retention in storage
(Toivonen, 2015). We found year-to-year consistency in $\mathrm{I}_{\mathrm{AD}}$ in 'Honeycrisp' between $\mathrm{ON}$ and in ME during harvest 2 in year 1, but not at other times. In $\mathrm{MN}, \mathrm{I}_{\mathrm{AD}}$ values were higher in year 1 compared with year 2 , but starch breakdown was also less advanced in year 1 compared with year 2 . Some of these year-to-year differences may be due to inconsistency in judging when to start harvest.

Orchard variability in $\mathrm{I}_{\mathrm{AD}}$ occurs in 'Honeycrisp' fruit when measured within a region (DeLong et al., 2014; Serra et al., 2016), but not in 'Starking' or 'Pink Lady' (Nyasordzi et al., 2013). We measured only one orchard in each region. Similarity in the range of $\mathrm{I}_{\mathrm{AD}}$ values during each harvest occurred among regions in most cases. However, regional inconsistencies occurred that could not be explained, such as $\mathrm{I}_{\mathrm{AD}}$ values that were twice as high in ME as in $\mathrm{ON}$ in 2017 despite greater starch breakdown in ME. Although the starch index can be influenced by cropload, temperature, and plant stress (Smith et al., 1979), it is often used as one indicator of fruit maturity. Small regional differences also occurred with 'McIntosh' that were not consistent with SPI. 


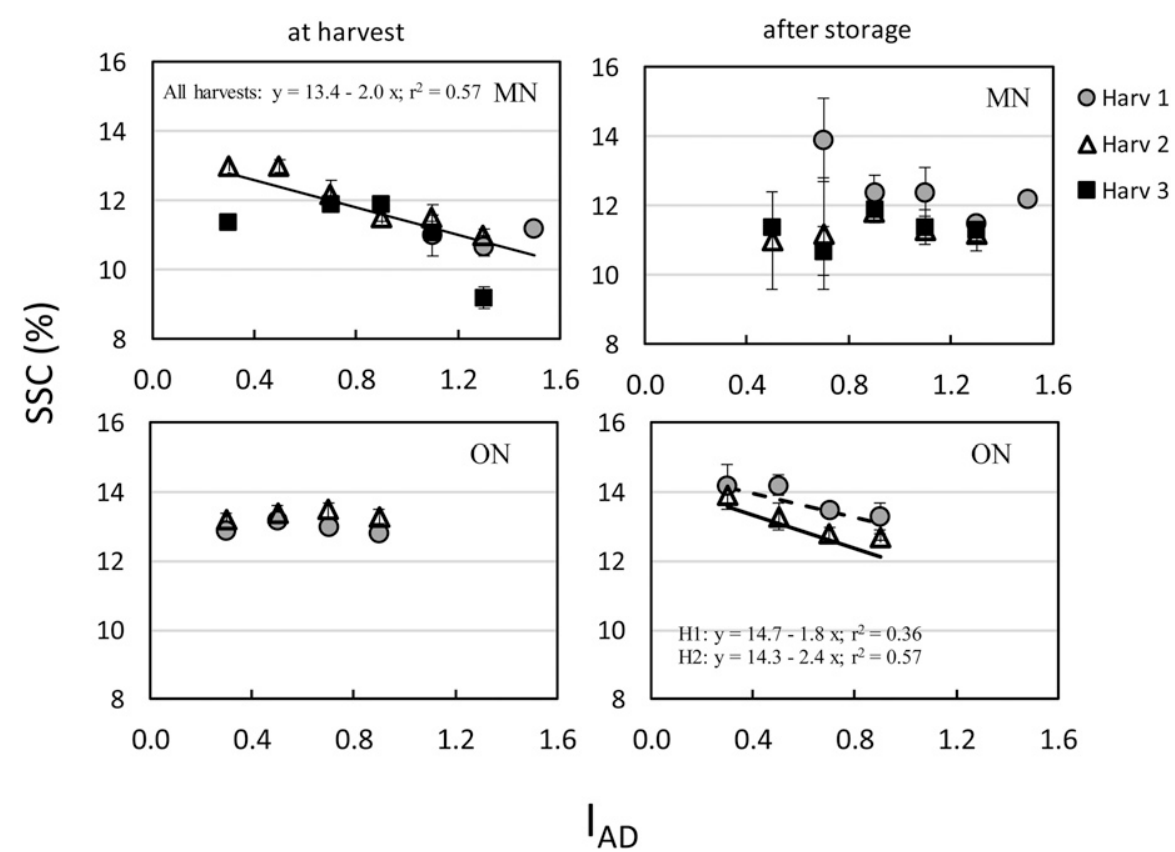

Fig. 7. The relationship between soluble solids concentration (SSC) at harvest and after storage with fruit peel $\mathrm{I}_{\mathrm{AD}}$ of 'Honeycrisp' fruit from $\mathrm{MN}$ and $\mathrm{ON}$ and three harvest dates. $\mathrm{H} 1$ and $\mathrm{H} 2$ indicate harvests 1 and 2 , respectively.

Table 6. Soft scald and soggy breakdown incidence after $0.5^{\circ} \mathrm{C}$ storage of 'Honeycrisp' apples grown in three regions for two years.

\begin{tabular}{|c|c|c|c|c|}
\hline \multirow[b]{2}{*}{ Factor } & \multicolumn{2}{|c|}{ Soft scald (\%) } & \multicolumn{2}{|c|}{ Soggy breakdown (\%) } \\
\hline & 2016 & 2017 & 2016 & 2017 \\
\hline$\overline{\mathrm{MN}}$ & $3.3 \mathrm{~b}^{2}$ & $6.8 \mathrm{~b}$ & 5.7 & 1.9 \\
\hline $\mathrm{ON}$ & $3.2 \mathrm{~b}$ & $26.6 \mathrm{ab}$ & 0.0 & 0.0 \\
\hline ME & $50.2 \mathrm{a}$ & $37.8 \mathrm{~b}$ & 42.7 & 22.7 \\
\hline Harvest 1 & $11.5 \mathrm{C}$ & $32.2 \mathrm{~A}$ & $7.5 \mathrm{C}$ & 6.6 \\
\hline Harvest 2 & $20.0 \mathrm{~B}$ & $9.3 \mathrm{~B}$ & $16.2 \mathrm{~B}$ & 7.4 \\
\hline Harvest 3 & $36.3 \mathrm{~A}$ & $22.4 \mathrm{AB}$ & $38.5 \mathrm{~A}$ & 14.5 \\
\hline \multicolumn{5}{|c|}{$P$ values for ANOVA Type III sums of squares } \\
\hline Region (R) & 0.0041 & 0.0025 & 0.1386 & 0.5613 \\
\hline Harvest (H) & 0.0107 & 0.0018 & 0.0336 & 0.2553 \\
\hline $\mathrm{I}_{\mathrm{AD}}$ Linear $(\mathrm{L})$ & 0.0184 & 0.0364 & 0.0012 & 0.4448 \\
\hline $\mathrm{R} \times \mathrm{H}$ & 0.0179 & 0.0117 & 0.7858 & 0.4783 \\
\hline $\mathrm{R} \times \mathrm{I}_{\mathrm{AD}} \mathrm{L}$ & 0.0087 & 0.0849 & 0.0001 & 0.0893 \\
\hline $\mathrm{H} \times \mathrm{I}_{\mathrm{AD}} \mathrm{L}$ & 0.1067 & 0.0237 & 0.0085 & 0.3199 \\
\hline $\mathrm{R} \times \mathrm{H} \times \mathrm{I}_{\mathrm{AD}} \mathrm{L}$ & 0.0160 & 0.0010 & 0.0013 & 0.0148 \\
\hline
\end{tabular}

${ }^{\mathrm{z}}$ Means separation by Tukey's test. Letters within a column followed by the same letter are not significantly different, $5 \%$ level. Arcsine transformed for analysis, but actual means are presented. Lowercase letters indicate differences among regions, and uppercase letters among harvests.

A strong relationship occurs between $\mathrm{I}_{\mathrm{AD}}$ and chlorophyll concentration when measured over a 9-week (DeLong et al., 2014) or 5-week (Shao et al., 2014) range in harvest dates. The correlation occurs in many cultivars (Shao et al., 2014), but it did not occur in our study with only a 2-week range in harvest dates, which may have been too narrow to ensure a sufficiently wide range in $\mathrm{I}_{\mathrm{AD}}$ values. In addition, the two cultivars had similar chlorophyll concentrations, but different ranges in $\mathrm{I}_{\mathrm{AD}}$. This occurs in 'Granny Smith' and 'Starking', as well, which had similar chlorophyll concentration, but $\mathrm{I}_{\mathrm{AD}}$ values that differed by 0.9 units (Nyasordzi et al., 2013).

In 'Honeycrisp' fruit, $\mathrm{I}_{\mathrm{AD}}$ was related to the maturity indicators IEC and SPI in both years, and to SPI to different degrees in all three regions. However, the relationship to SPI was not the same for each harvest date in 2016 because starch breakdown occurred faster than reduction in $\mathrm{I}_{\mathrm{AD}}$ and was nearly complete by the third harvest. $\mathrm{I}_{\mathrm{AD}}$ correlation with peel blush occurred in 'Honeycrisp' fruit in all three regions and with the same relationship for all three harvests, indicating the two traits are closely linked under the growing conditions in this study. However, the relationship of peel blush and $\mathrm{I}_{\mathrm{AD}}$ in $\mathrm{MN}$ was weaker and with a smaller slope in $\mathrm{MN}$ than in $\mathrm{ON}$ and ME.

In this study, the region where fruit were grown and stored was more important in determining susceptibility to SSI than harvest maturity. However, only one orchard was sampled within each region, so conclusions regarding regional variation may be because of differences between the three orchards. Soft scald incidence was sometimes more severe in fruit harvested earlier rather than later, as in the case of $\mathrm{MN}$ and $\mathrm{ON}$ in 2017, indicating that SSI is not consistently more severe in fruit with advanced maturity. A decrease in SSI with later harvest date was previously reported for Michigan-grown 'Honeycrisp' (Watkins et al., 2005). In ME, SSI had a negative relationship to $\mathrm{I}_{\mathrm{AD}}$ during the first harvest, indicating an increase in susceptibility with advanced maturity. However, the relationship of SSI and $\mathrm{I}_{\mathrm{AD}}$ switched from negative to positive during the harvest window in $\mathrm{ME}$ as mean $\mathrm{I}_{\mathrm{AD}}$ decreased below 0.8 , as in $\mathrm{ON}$ in 2017 where it was positive for all three harvests. This positive relationship to $\mathrm{I}_{\mathrm{AD}}$ also occurred in the same orchard in 2015 with the latter harvest when SSI was severe (Moran, 2018). This indicates a consistent year-to-year trend in ME, where SSI is typically severe. In these cases, the relationship to $\mathrm{I}_{\mathrm{AD}}$ was positive, indicating reduced susceptibility in fruit with more advanced maturity when examining fruit from within a harvest date. Al Shoffe et al. (2020) found no linear correlation between $\mathrm{I}_{\mathrm{AD}}$ and SSI in fruit grown in Pennsylvania and New York. Harvest date has a large, but inconsistent effect on 'Honeycrisp' fruit disorder occurrence, such that the same $\mathrm{I}_{\mathrm{AD}}$ value may result in a low incidence of SSI for one harvest, but a high incidence for a different harvest. 'Honeycrisp' fruit ripening and disorder development seems to be sensitive to environmental conditions (Lachapelle et al., 2013; Moran et al., 2009), so there can be much variation in the timing of various fruit ripening characteristics (change in background color, ethylene production, rate of starch loss, etc.) within and among orchards.

\section{Conclusions}

$\mathrm{I}_{\mathrm{AD}}$ was useful as an adjunct to other measures of maturity in 'Honeycrisp' fruit, with some consistency in the range in values among two of three regions in each year. The greatest degree of regional disparity in $\mathrm{I}_{\mathrm{AD}}$ values occurred with the first harvest but was reflective of disparity in SPI among the regions during harvest $1 . \mathrm{I}_{\mathrm{AD}}$ measured changes in 'McIntosh' fruit maturity in one of the three regions in this study, but the decrease in $\mathrm{I}_{\mathrm{AD}}$ with later harvest was too small in the other two regions. This may reflect the use of different sports of 'McIntosh' grown at the different regions. Incidence of bitter pit was not predicted by $\mathrm{I}_{\mathrm{AD}}$ at harvest, whereas SSI was predicted by $\mathrm{I}_{\mathrm{AD}}$, but only in two regions and in contrasting ways from harvest to harvest. Due to regional and yearly inconsistencies, growers should use $\mathrm{I}_{\mathrm{AD}}$ data as one of several methods, such as SPI and change in ground color, to judge 'Honeycrisp' apple maturity. $\mathrm{I}_{\mathrm{AD}}$ was not useful for measuring maturity in 'McIntosh' apples but was weakly related to core browning incidence. 

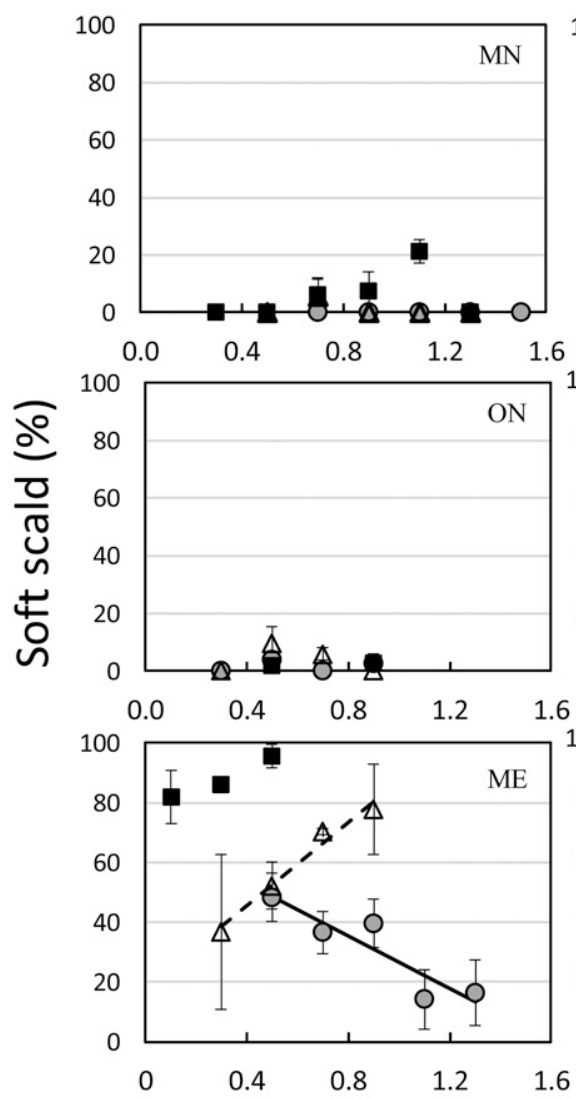

H1: $y=71-44 x ; r^{2}=0.42$

$\mathrm{H} 2: \mathrm{y}=18+70 \mathrm{x} ; \mathrm{r}^{2}=0.44$

\section{I}
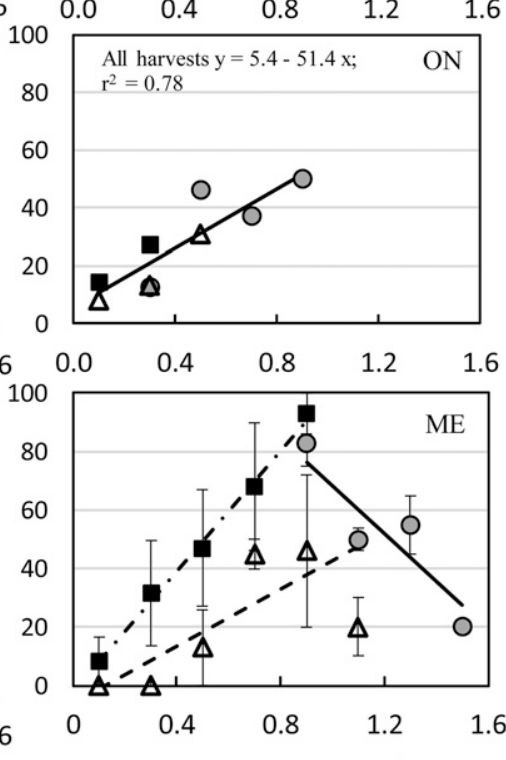

\section{$A D$}

2017

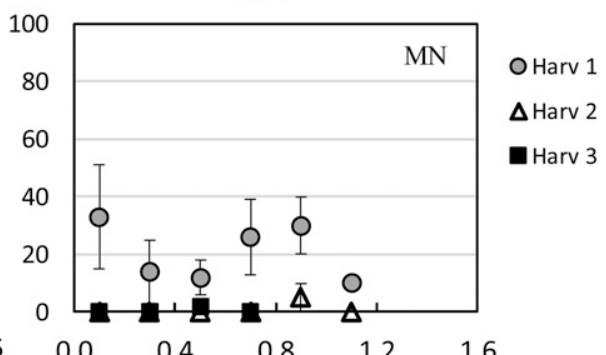

Fig. 8. The relationship between soft scald incidence in 'Honeycrisp' and fruit peel $\mathrm{I}_{\mathrm{AD}}$ at harvest in three locations and 2 years. $\mathrm{H} 1, \mathrm{H} 2$, and $\mathrm{H} 3$ indicate harvests 1,2 , and 3, respectively.

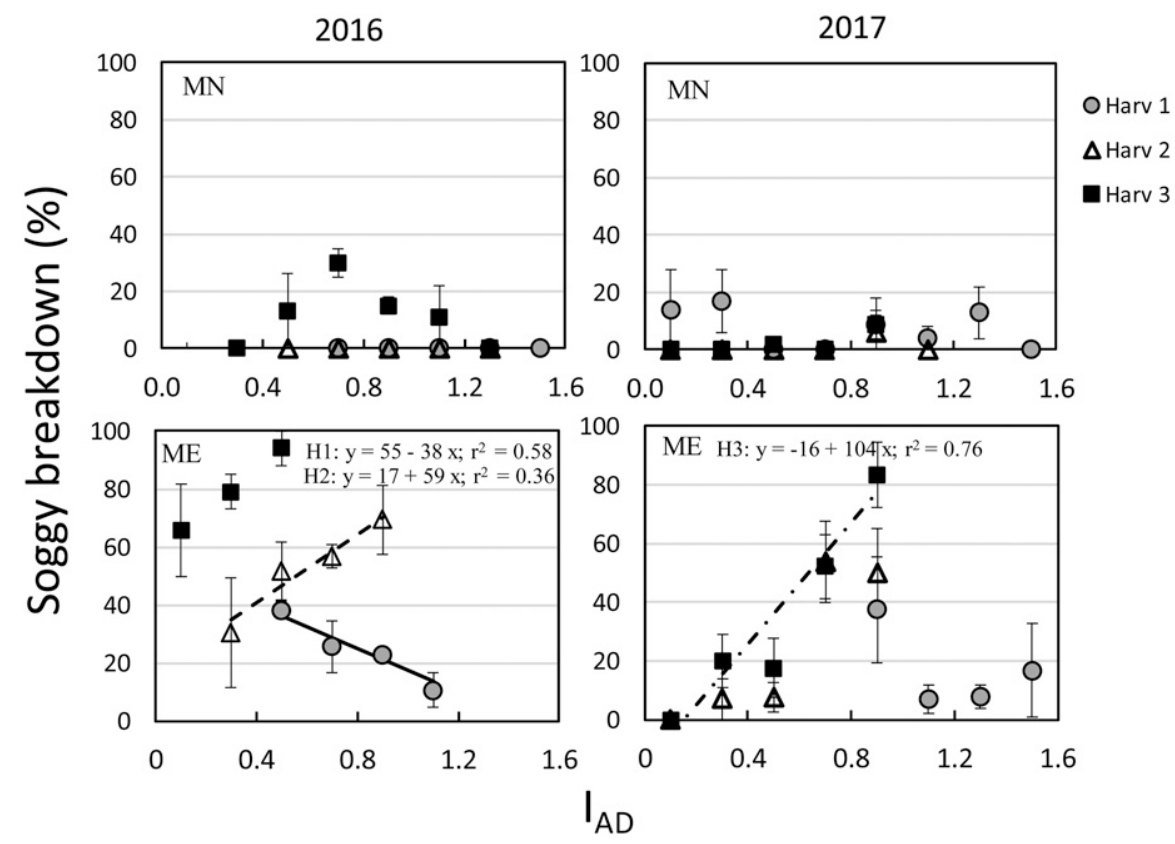

Fig. 9. The relationship between soggy breakdown incidence in 'Honeycrisp' fruit and fruit peel $\mathrm{I}_{\mathrm{AD}}$ at harvest in MN and ME and 2 years. Soggy breakdown did not occur in ON apples. H1, H2, and H3 indicate harvests 1,2 , and 3 , respectively.

\section{Literature Cited}

Al Shoffe, Y., J.F. Nock, T.A. Baugher, R.P. Marini, and C.B. Watkins. 2020. Bitter pit and soft scald development during storage of unconditioned and conditioned 'Honeycrisp' apples in relation to mineral contents and harvest indices. Postharvest Biol. Technol. 160: 111044.

Blanpied, G.D. and K. Silsby. 1992. Predicting harvest date windows for apples. Cornell Univ. (Ithaca, N.Y.) Info. Bul. 221.

DeLong, J., R. Prange, P. Harrison, D. Nichols, and H. Wright. 2014. Determination of optimal harvest boundaries for 'Honeycrisp'TM fruit using a new chlorophyll meter. Can. J. Plant Sci. 94:361-369.

Dilley, C.L. and D.R. Dilley. 1985. New technology for analyzing ethylene and determining the onset of the ethylene climacteric of apples, p. 353-362. In: S.M. Blankenship (ed.). Natl. Controlled Atmosphere Res. Conf. 4th Proc

Doerflinger, F.C., J.F. Nock, Y. Al Shoffe, X. Shao, and C.B. Watkins. 2016. Non-destructive maturity assessment of 'Empire' apples treated with preharvest inhibitors of ethylene perception and production with a delta absorbance (DA) meter. Acta Hort. 1119:227-233.

Farneti, B., M.S. Gutierrez, B. Novak, N. Busatto, D. Ravaglia, F. Spinelli, and G. Costa. 2015. Use of the index of absorbance difference $\left(\mathrm{I}_{\mathrm{AD}}\right)$ as a tool for tailoring post-harvest 1-MCP application to control apple superficial scald. Scientia Hort. 190:110-116.

Knee, M. 1972. Anthocyanin, carotenoid, and chlorophyll changes in the peel of Cox's Orange Pippin apples during ripening on and off the tree. J. Expt. Bot. 23:184-196.

Lachapelle, M., G. Bourgeois, J.R. DeEll, K.A. Stewart, and P. Séguin. 2013. Modelling the effect of preharvest weather conditions on the incidence of soft scald in 'Honeycrisp' apples. Postharvest Biol. Technol. 85:57-66.

Lichtenthaler, H.K. 1987. Chlorophylls and carotenoids: Pigments of photosynthetic biomembranes. Methods Enzymol. 148:350-382.

Meheriuk, M., R.K. Prange, P.D. Lidster, and S.W Porritt. 1994. Postharvest disorders of apples and pears. Agr. and Agri-Food Canada Pub. $1737 / \mathrm{E}$.

Moran, R. 2018. Using the DA meter to predict harvest maturity in 'Honeycrisp' and 'McIntosh' apples. HortScience 53:S176 (abstr.).

Moran, R.E., J.R. DeEll, and W. Halteman. 2009. Effects of preharvest precipitation, air temperature, and humidity on the occurrence of soft scald in 'Honeycrisp' apples. HortScience 44:1645-1647.

Nyasordzi, J., H. Friedman, Z. Schmilovitch, T. Ignat, A. Weksler, I. Rot, and S. Lurie. 2013. Utilizing the $\mathrm{I}_{\mathrm{AD}}$ index to determine internal quality attributes of apples at harvest and after storage. Postharvest Biol. Technol. 77:80-86.

Serra, S., R. Leisso, L. Giordani, L. Kalcits, and S Musacchi. 2016. Crop load influences fruit quality, nutritional balance, and return bloom in 'Honeycrisp' apple. HortScience 51:236244.

Shao, X., Y. Al Shoffe, F. Doerflinger, H. Gao, J. Nock, and C. Watkins. 2014. DA meter readings and chlorophyll content on the blushed and unblushed sides of nine apple cultivars. HortScience 49:S259 (abstr.).

Smith, R.B., E.C. Lougheed, E.W. Franklin, and I. McMillan. 1979. The starch iodine test for determining stage of maturation in apples. Can. J. Plant Sci. 59:725-735. 
Smock, R.M. 1977. Nomenclature for internal storage disorders of apples. HortScience 12: 306-308.

Toivonen, P. 2015. Comparison of $\mathrm{I}_{\mathrm{AD}}$ and starchiodine indices at harvest and how they relate to post-storage firmness retention in Ambrosia ${ }^{\mathrm{TM}}$ apples over three growing seasons. Can. J. Plant Sci. 95:1177-1180.

Toivonen, P. and C. Hampson. 2014. Relationship of the $I_{A D}$ index to internal quality attributes of apples treated with 1-methylcyclopropene and stored in air or controlled atmospheres. Postharvest Biol. Technol. 91:90-95.

Watkins, C.B., M. Erkan, J.F. Nock, K.A. Iungerman, R.M. Beaudry, and R.E. Moran. 2005. Harvest date effects on maturity, quality, and storage disorders of 'Honeycrisp' apples. HortScience 40:164-169. 